\title{
Barbel species arrangement in a regional Natura 2000 network (Emilia Romagna, Northern Italy): An altitudinal perspective
}

\author{
Federica PICCOLI,, Gemma BURGAZZI," Alex LAINI, Claudio FERRARI, Andrea VOCCIA, Laura FILONZI, \\ Rossano BOLPAGNI, Francesco NONNIS MARZANO*
}

Department of Chemistry, Life Sciences and Environmental Sustainability, University of Parma, Parco Area delle Scienze 11/A, I-43124 Parma, Italy

\#Both authors have contributed equally to this research

*Corresponding author: francesco.nonnismarzano@unipr.it

\begin{abstract}
Southern Europe hosts a large number of critical catchments for freshwater biodiversity, including endemic fish species. Unfortunately, these areas are severely threatened due to direct and indirect anthropogenic effects. In this context, with the aim to improve the effectiveness of threatened fish protection, the Life project BARBIE (LIFE13 NAT/IT/001129) started in 2014 and focused on three congeneric species of the genus Barbus: two of "priority interest" sensu Habitats Directive [Barbus caninus (Bonaparte, 1839), and B. plebejus (Bonaparte, 1839)], and one alien [Barbus barbus (Linnaeus, 1758)]. Our main objective was to assess the contribution of a complex of protected areas included in the Natura 2000 network - located in the provinces of Parma, Piacenza and Reggio Emilia (Norther Italy) - to support the presence of the three barbel species in analysis. Additionally, we explored the role of a set of environmental variables (i.e., physical, chemical, biological, and land-use descriptors) to drive the current conditions of the study sites and the responses of Barbus species. As a general rule, the present study confirmed a clear decline of the local native barbel populations, and confirmed the existence of a zonation pattern of the barbel taxa. Hence, we observed a strong altitude segregation between native $v s$. alien species, with the exotic $B$. barbus currently limited to plain and only sporadically present in the Apennine areas as genetic introgression. These evidences mirrored the altitudinal gradients of anthropogenic disturbance. The main causes were the progressive disappearance of well-structured riparian stripes, and the intense land use change, ranging from semi-natural patches (mountain and hill sectors) to land clearing for intensive agriculture (lowland sectors). This highlights the need to take into account the spatial dynamics of alien invasive species in programming recovery actions that could have unexpected impacts to the native fish populations, for example the reduction of the hydraulic fragmentation along rivers.
\end{abstract}

Key word: Barbus genus species; inland waters; endangered fish; Habitats Directive; Fluvial Functionality Index; physical and chemical drivers.

\section{INTRODUCTION}

Since streams and rivers have become some of the most endangered ecosystems worldwide, there is an urgent demand for comprehensive methodological approaches to evaluate their conservation status, and to monitor their rate of changes (Li et al., 2010). Mediterranean regions represent key areas for freshwater fish endemism and introductions (Leprieur et al., 2008). Indeed, a large portion of the European critical catchments for freshwater biodiversity is located primarily in southern Europe (Carrizo et al., 2017). Unfortunately, these areas are severely threatened because of water scarcity and environmental degradation due to the high anthropic pressure (e.g., hydropower, agriculture, public uses), and to the on-going climate change (Hermoso and Clavero, 2011; Hermoso et al., 2011).

In inland waters, the natural fish stocks are generally over-exploited, and in the developed countries, uncontrolled larvae and juveniles' reintroduction have been carried out for recreational fishery purposes (Lewin et al.,
2008). Additionally, in last decades the distributions of many exotic fish species have extended worldwide further impairing the quality of autochtonous fish populations (Carosi et al., 2017). This is especially true for Italy, particularly along the lower stretches of rivers throughout the Apennines (Italian Peninsula) that are characterized by rather warm and slow waters, and scarce quality conditions (Carosi et al., 2017). All this translates into less than ideal conditions for the survival of endemic and threatened fish, and the conservation of the local population diversity.

Since the beginning of $21^{\text {st }}$ century, to counteract the above-mentioned critical issues many actions have been carried out to improve fish population, including mitigation of hydropower development, river fragmentation and hydropeaking (Premstaller et al., 2017). In this context, the Natura 2000 network may represent a strategic tool to preserve both fish genetics and population resources, with the final goal of improving their local and regional survival chances. However, the designation procedures of the Natura 2000 sites often are driven by factors marginally 
related to ecological criteria, thus reducing their effectiveness (Trochet and Schmeller, 2013). Furthermore, the biotic integrity of biological communities in rivers and lakes is considered a key predictor of colonized water bodies' quality suggesting a strong synergy between the Habitat Directive (HD; European Commission, 1992) and the Water Framework Directive (WFD; European Commission, 2000). However, unfortunately, these two fundamental legal issues proceed in isolation with negative effects on their relative efficiency (Bolpagni et al., 2017).

In order to actively and mutually implement the HD and the WFD, and with the aim to improve their effectiveness in terms of threatened fish protection, the Life project BARBIE (LIFE13 NAT/IT/001129) started in 2014, focusing on three congeneric species of the genus Barbus. Two of them are of "priority interest" sensu HD: Barbus caninus (Bonaparte, 1839) and B. plebejus (Bonaparte, 1839). This two native species of Barbus are charismatic indicators for the estimation of the conservation status of water bodies (Angelini et al., 2016). The third is an alien species, Barbus barbus (Linnaeus, 1758), that in the last decades - showed an exceptionally fast spreading capacity within the Po River basin. This invasive species has also hybridized with the endemic $B$. plebejus (Meraner et al., 2013), thus resulting in a widespread genetic introgression in the autochthon Barbus species.

In this context, to test the distinct distribution of the different species as per our hypothesis, we described the fish community structure in a representative array of 14 of the watercourses included in the Natura 2000 sites - and their surroundings - of the Parma, Piacenza and Reggio Emilia provinces (Emilia Romagna Region, Northern Italy). Our main hypothesis is that the exotic taxon (B. barbus) may be spatially limited to the lowland sectors, which are those with the highest human disturbance rates. On the contrary, prior barbel taxa (B. caninus and B. plebejus) are expected to be mainly distributed in mountain and/or hill areas. In other words, altitudinal segregation between these species may be hypothesized. To do this, we focused on the presence/absence and representativeness of the Barbus species, implementing the current data on their local spatial distribution. In this way, we were also able to assess the contribution of a complex of Natura 2000 sites to support fish communities. Additionally, we collected a set of environmental variables (including physical, chemical, biological, and land-use descriptors) to assess the current conditions of sites colonized by the different species in analysis.

\section{METHODS}

\section{Study area}

This study covered rivers and streams running along 14 sites of the Natura 2000 network of the Parma, Piacenza and Reggio Emilia provinces (Emilia Romagna region, Northern Italy; Fig. 1 and Supplementary Tab. 1). The Köppen-Geiger classification includes both humid subtropical (cfa; plains and hill sectors) and oceanic climates (cfb; mountain sector), characterized by few extremes of temperature and pronounced precipitation in all months.

The study area includes a complex hydro-system that consists of several streams and rivers across an extended altitudinal range (about $600 \mathrm{~m}$ ), stretching from the Tuscan-Emilian Apennine ridge to the Po River. Accordingly, the mean annual discharges and the main water chemical and physical conditions are extremely variable. Generally, the investigated water bodies showed a good chemical status, and fall into the sufficient or good quality classes of the ecological status sensu WFD (ARPA Emilia Romagna, 2013). The study area covers the entire distribution range of the two autochthonous target species in the Emilia Romagna region: canine barbel (B. caninus) inhabits mountain fast-flowing brooks and small rivers while the common barbel (B. plebejus) commonly occurs in hilly and lowland streams.

\section{Biological, water quality and morphological characterization}

Between July 2014 and December 2015, a total of 305 barbel individuals were collected by electric fishing (Macchio and Rossi, 2014), from 31 localities of the study area. Each animal was measured and fin-clipped and then released in the same location. Measurements included the total length and the weight. Fin fragment were preserved in $70 \%$ ethanol until DNA extraction. Starting from the visual based analysis of the fish community, the Index of the Ecological Status of Fish Communities (ISECI) was also calculated in each of the 31 study sites, according with Zerunian (2009) protocol.

Simultaneously with the fish characterization, a water sample was collected by a plastic bottle just below the water surface. Directly in situ temperature, $\mathrm{pH}$, conductivity and dissolved oxygen data were collected by a multi-parameter probe (YSI model 556 MPS). Samples for the biochemical oxygen demand (BOD) were transferred in glass bottles. Samples for $\mathrm{NH}_{4}^{+}$(ammonium), $\mathrm{NO}_{3}^{-}$(nitrate), and $\mathrm{NO}_{2}^{-}$(nitrite) determinations were filtered through Whatman $\mathrm{GF} / \mathrm{F}$ glass fiber filters ( $\varnothing 47 \mathrm{~mm}$, porosity $0.45 \mu \mathrm{m})$ and transferred to plastic vials. All water samples were kept to $4^{\circ} \mathrm{C}$, and transferred to the laboratory. Total suspended solids (TSS) were measured by filtration through a pre-dried and weighed glass fiber filter $\mathrm{GF} / \mathrm{F}$ (Whatman, UK, $\varnothing 25 \mathrm{~mm}$ and $0.45 \mu \mathrm{m}$ ) (APHA, 2012). $\mathrm{NH}_{4}^{+}, \mathrm{NO}_{3}^{-}, \mathrm{NO}_{2}^{-}$, were determined with standard spectrophotometric methods APHA (2012), whereas BOD was calculated after incubation at $20 \pm 1^{\circ} \mathrm{C}$ for 5 days $\left(=\mathrm{BOD}_{5}\right)$ according to APHA (2012).

Each sampling sites was characterized by the applica- 
tion of the Fluvial Functionality Index (FFI), that is devoted to investigate the functionality of a river stretch in terms of metabolic capacity (i.e., fine and coarse particulate organic matter retention and cycling) (Siligardi et al., 2000). This method is based on the analysis of riverbank vegetation, physical and morphological structure, the extent of the riparian area, the land use impact, the riverbed structure, and the key biological characteristics of river ecosystem. For further details, see Siligardi et al. (2000).

\section{Molecular data analysis}

Total genomic DNA was extracted from fin tissue using Wizard genomic DNA Purification kit (PROMEGA, Madison, WI, USA). DNA quality and concentration were tested by $1 \%$ agarose gel electrophoresis in $1 \%$ TAE buffer, by visual comparison with a DNA ladder mix and by spectrophotometry at 260 e $280 \mathrm{~nm}$. The extraction procedure typically yielded not less than 40 ng/mL of HMW (high molecular weight) DNA. For each of 305 specimens we analysed $600 \mathrm{bp}$ long region of the cytb mtDNA and was amplified by polymerase chain reaction (PCR) using primer pair CYTB-Thr 5' -ACCTCCGATCTTCGGATTACAAGACCG-3' and CYTB-Glu 5'-AACCACCGTTGTATTCAACTACAA - 3' (Zardoya and Doadrio, 1998). A reaction volume of $25 \mu 1$ containing $1 \mathrm{U}$ of GoTaq Polymerase (PROMEGA, Madison, WI, USA), $\mathrm{Mg}^{2+} 1.5 \mathrm{mM}$ and dNTPs $0.2 \mathrm{mM}$, and 10 pmol of each primer were used. PCR was set as follows: 35 cycles of $45 \mathrm{~s}$ at $94^{\circ} \mathrm{C}, 1 \mathrm{~min}$ at $47^{\circ} \mathrm{C}$, and $2 \mathrm{~min}$ at $72^{\circ} \mathrm{C}$, after an initial 3 min denaturation step at $94^{\circ} \mathrm{C}$ and a final extension at $72^{\circ} \mathrm{C}$ for $10 \mathrm{~min}$. Fragments sequencing was performed by MACROGEN Europe service (Amsterdam, the Netherlands). The obtained sequences were manually corrected using MEGA7.0 and were compared with those available in genomic databases using NCBI BLAST.

\section{Statistical analysis}

A principal component analysis (PCA) was performed on chemical and physical data. The interpretation of PCA

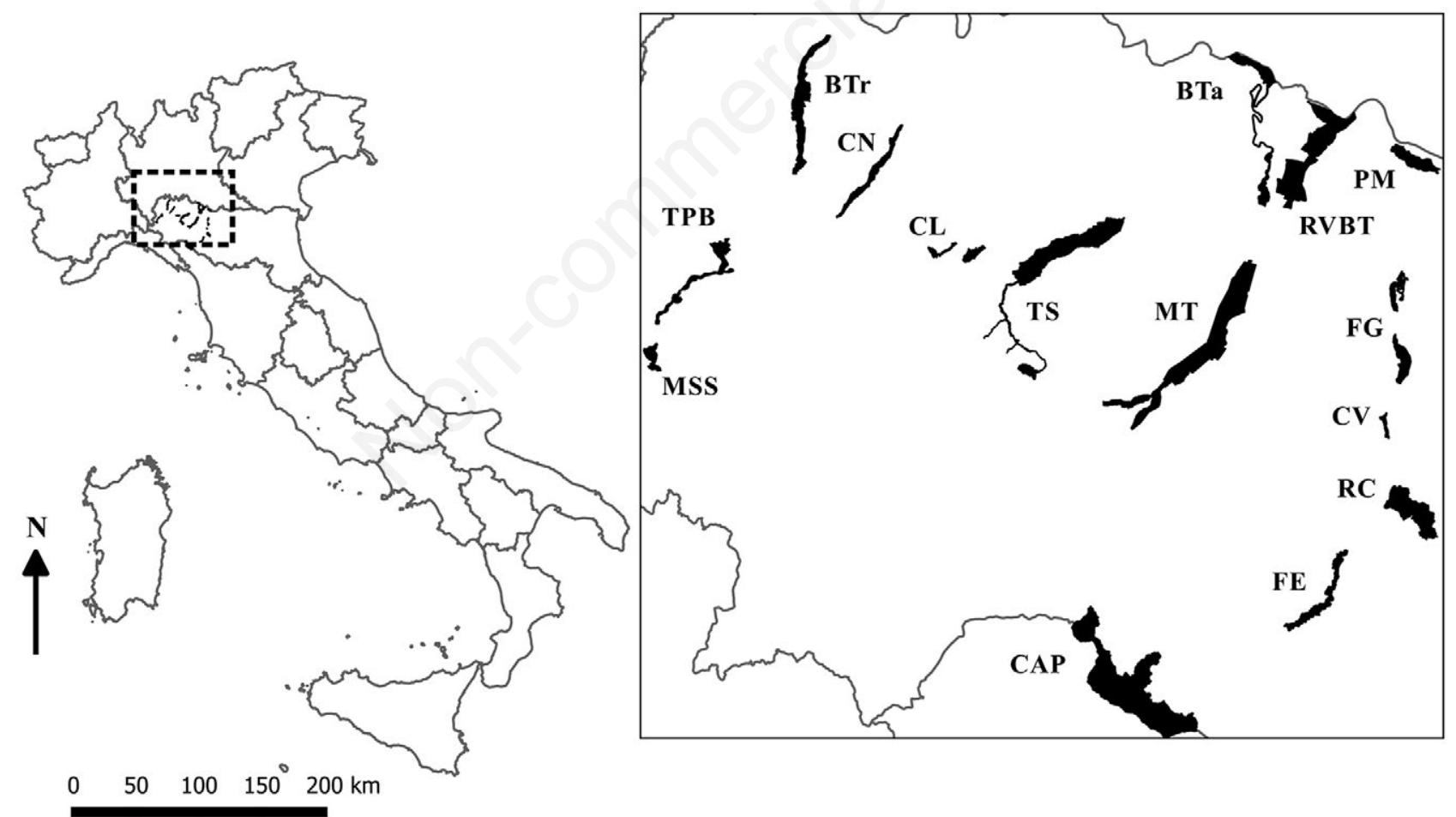

Fig. 1. Study area with the indication of the Natura 2000 network. MSS, Trebbia - Meandri di San Salvatore (IT4010006); TPB, Trebbia River - from Perino to Bobbio (IT4010011); BTr, Low Trebbia River (IT4010016); CN, Nure River - Conoide del Nure and Bosco di Fornace Vecchia (IT4010017); CL, Arada River - Castell'Arquato, Lugagnano Val d'Arda (IT4010008); TS, Stirone Stream (IT4020003); Bta, Low Taro River (IT4020022); RVBT, Lorno River - Aree delle risorgive di Viarolo, Bacini di Torrile, Fascia golenale del Po (IT4020017); PM, Parma Morta (IT4020025); MT, Medium Taro River (IT4020021); FG, Enza River - Fontanili di Gattatico (IT4030023); CV, Enza River - Cronovilla (IT4020027); RC, Cerezzola Stream - Rupe di Campotrera, Rossena (IT4030014); FE, Enza River - from La Mora to Compiano (IT4030013); CAP, Parma - Crinale dell'Appennino parmense (IT4020020). 
ordination was limited to variables with loads higher than the vector representing a variable contributing equally to all the dimensions of the PCA space (Borcard et al., 2011). The relationship between PCA ordination and the structure of Barbus' populations was assessed by means of the function envfit ("vegan" package) that fits vectors onto a multivariate ordination. Simple regression analysis was used to examine the relationships between FFI and altitude and $\mathrm{BOD}_{5}$ values.

All the analyses and graphs were performed with the statistical software R (R Core Team, 2015), with base version, ggplot2 (Wickham, 2009) and vegan (Oksanen et al., 2016) packages.

\section{RESULTS}

\section{Water quality and morphological characterization of sites}

Physical, chemical, and morphological (i.e., FFI outputs) data are reported in Supplementary Tab. 1. Results from water measurements highlight the variability between sites in terms of altitude and human impact gradients. In summer 2015, temperature, $\mathrm{pH}$, dissolved oxygen, and conductivity were in the ranges $14.4-31.0^{\circ} \mathrm{C}, 7.30$ $8.91,37-295 \%$ saturation, and $190-825 \mu \mathrm{S} \mathrm{cm}{ }^{-1}$, respectively. Similarly, the $\mathrm{BOD}_{5}$ and TSS values varied from 0.0 (mountain sites, Trebbia River) to $20.8 \mathrm{mg} \mathrm{L}^{-1}$ (lowland site, Parma Morta), and from 0.0 to $66.2 \mathrm{mg} \mathrm{L}^{-1}$, respectively. At the same time, $\mathrm{NH}_{4}^{+}$and $\mathrm{NO}_{2}^{-}$ concentrations exhibited only small variations, within the range 0.02-0.04 $\mathrm{NH}_{4}^{+} \mathrm{mg} \mathrm{N} \mathrm{L}^{-1}$, and 0.00-0.02 $\mathrm{NO}_{2}^{-} \mathrm{mg}$ $\mathrm{N} \mathrm{L}^{-1}$. On the contrary, $\mathrm{NO}_{3}{ }^{-}$ranged between 0.08 and $5.00 \mathrm{mg} \mathrm{N} \mathrm{L}^{-1}$.

FFI ranged between 102 and 245, from poor/bad to good classes. It showed a clear spatial arrangement with a tendentially significant negative correlation with altitude $(\mathrm{r}=0.45, \mathrm{P}=0.07 ; \mathrm{n}=17)$. A progressive reduction in FFI values was recorded from mountain/hill sectors to lowlands. On the contrary, no significant relationship between FFI and $\mathrm{BOD}_{5}$ values was recorded $(\mathrm{r}=0.37, \mathrm{P}>0.1 ; \mathrm{n}=17)$, although a gradual increase of the biochemical oxygen demand with the progressive loss of the functionality of riparian belt is generally expected.

\section{Fish community and ISECI assessment}

The number of individuals detected in each sampling station for the three investigated species is reported in Tab. 1. From a general point of view, considering the population size (expressed in terms of number of individuals), the observed data were quite low in the range 0-29 individuals. Considering species separation, mean values $( \pm$ standard deviation) were $1.0( \pm 3.5), 1.8( \pm 6.1)$, and 7.1 $( \pm 8.4)$ individuals for alien European barbel, canine, and common respectively. Eight over 31 (26\%) study sites showed complete absence of barbel specimens.

A structured population of canine barbel constituted of 24 and 25 specimens were retrieved in the streams Rio Cerezzola (Natura 2000 site IT4030014) and Rio Parmossa (bordering this Natura 2000 site area), respectively. On the contrary, common barbel peaked at Nure and Enza rivers with 29 and 25 individuals, respectively. The alien European barbel species colonized 7 (23\%) study sites belonging to Arda, Trebbia, Taro, Ceno and Enza rivers, besides Naviglio channel (Tab. 1). In particular, the alien European barbel showed a representative population in Taro River, with 19 individuals, as a result of the only investigated plain river site.

The ISECI values varied from 0.72 (good ecological quality) at Nure River to 0.20 (poor ecological quality) at lowland site Parma Morta, with a mean value of 0.57 $( \pm 0.14)$ (sufficient ecological quality) (Tab. 1). More specifically, 18 over 31 (58\%) sites displayed "good quality" class, 10 (32) "moderate quality", 1 (3\%) "poor quality", and 2 (7\%) "bad quality”.

Molecular analyses provided data on the percentage of different species at sampling site level (Tab. 1). Fragments of 600 bps were analyzed and compared to GenBank sequences. Samples displayed 100\% identity with deposited sequences according to different species with alignment values $\mathrm{E}=0.0$ and maximum identity in the range $97-100 \%$. ClustalW assessment among investigated samples showed a total number of 230 polymorphic sites. From a taxonomy point of view, molecular analyses on mtDNA evidenced the following density values: $72 \%$ common barbel, 18\% canine barbel, and 10\% alien European barbel.

In terms of environmental drivers of the observed barbel' species spatial distribution, FFI and oxygen saturation were the variables contributing most to respectively PCA axes 1 and 2, explaining the $88 \%$ of the total variance. Alien European barbel was significantly related to the PCA ordination $\left(\mathrm{R}^{2}=0.67, \mathrm{P}<0.05\right)$, while this was not true for the other two barbel species: B. caninus $\left(\mathrm{R}^{2}=0.15\right.$, $\mathrm{P}>0.05)$ and B. plebejus $\left(\mathrm{R}^{2}=0.14, \mathrm{P}>0.05\right)$ (Fig. 2).

\section{DISCUSSION AND CONCLUSIONS}

Our results confirmed a decline of native barbel populations in the study area compared with literature data (Nonnis Marzano et al., 2003; Fish Charts Provinces of Parma, Reggio Emilia, and Piacenza). Barbel populations were historically present in several streams of the three provinces, both in the mid-Apennine and hillsides (Nonnis Marzano et al., 2003). However, a well-structured population of the canine barbel was retrieved only in two sampling stations, highlighting a local high degree of rarity for this species. Additionally, in agreement with our initial hy- 
potheses the present data confirmed the general existence of a clear zonation pattern among the barbel species analyzed, although a frequent overlapping of populations limited statistical significance of principal component analysis. A non-negligible altitude segregation between native $v s$. alien species was detected, with the exotic invasive $B$. barbus mainly limited to lowland watercourses. We also detected invasive $B$. barbus DNA in the native populations of the hill areas as a result of genetic introgression. These observations corroborate recent evidence on the rapid expansion of the European barbel in the Po basin (Meraner et al., 2013), and indicate a higher level of vulnerability for the autochthonous fish populations placed at lower altitudes, where the likely presence of alien barbels is wider. It is noteworthy observing that migration of $B$. barbus mitochondrial haplotypes reaching hill and mid-Apennines catchments could be referred to water heating due to global warming and water deprivation.

More specifically, the species spatial distribution mirrored the anthropogenic disturbance gradients. In fact, all the investigated sites are arranged along an altitudinal gradient stretching from the Tuscan-Emilian Apennine (up to $600 \mathrm{~m}$ asl) to the Po River ( $\sim 25 \mathrm{~m}$ asl), that overlaps with human pressures, which significantly decreases

Tab. 1. Barbus' population size and ISECI results; for each sampled site, the indication of each watercourse and the Natura 2000 site it belongs, the number of individuals and their \% distribution value (in brackets) of Canine (B. caninus), Common (B. plebejus), and alien European (B. barbus) Barbel, the values and quality class of ISECI were reported. In bold the sites without barbels.

\begin{tabular}{|c|c|c|c|c|c|c|c|c|}
\hline \multirow[t]{2}{*}{ Site } & \multirow[t]{2}{*}{ Watercourse } & \multirow[t]{2}{*}{ Code } & \multirow{2}{*}{$\begin{array}{l}\text { Natura } 2000 \\
\text { site code }\end{array}$} & \multicolumn{2}{|c|}{ Number of individuals } & \multirow[b]{2}{*}{ European } & \multicolumn{2}{|l|}{ ISECI } \\
\hline & & & & Canine & Common & & Value & Quality class \\
\hline 10006.TR.1 & Trebbia & MSS & IT4010006 & $1(7.5 \%)$ & $15(92.5 \%)$ & 0 & 0.61 & Good \\
\hline 10008.AR.1 & Arda & CL & IT4010008 & 0 & $23(95.8 \%)$ & $1(4.2 \%)$ & 0.61 & Good \\
\hline 10011.TR.1 & Trebbia & ТPB & IT4010011 & $2(12.5 \%)$ & $14(87.5 \%)$ & 0 & 0.64 & Good \\
\hline 10016.TR.1 & Trebbia & $\mathrm{BTr}$ & IT4010016 & 0 & $15(75.0 \%)$ & $5(25.0 \%)$ & 0.72 & Good \\
\hline 10016.TR.2 & Trebbia & $\mathrm{BTr}$ & IT4010016 & $\mathbf{0}$ & O & $\mathbf{0}$ & 0.69 & Good \\
\hline 10017.NU.1 & Nure & $\mathrm{CN}$ & IT4010017 & 0 & $29(100.0 \%)$ & 0 & 0.72 & Good \\
\hline 20003.ST.1 & Stirone & $\mathrm{TS}$ & IT4020003 & 0 & $13(100.0 \%)$ & 0 & 0.71 & Good \\
\hline 20017.LO.1 & Lorno & RVBT & IT4020017 & $\mathbf{0}$ & $\mathbf{0}$ & $\mathbf{0}$ & 0.66 & Good \\
\hline 20020.PR.1 & Parma & & - & 0 & $3(100.0 \%)$ & 0 & 0.40 & Poor \\
\hline 20020.PR.2 & Parma & & - & $1(11.1 \%)$ & $8(88.9 \%)$ & 0 & 0.52 & Moderate \\
\hline 20020.PR.3 & Parma & CAP & IT4020020 & 0 & 0 & 0 & 0.66 & Good \\
\hline 20020.PM.1 & Parmossa & & - & $25(89.3 \%)$ & $3(10.7 \%)$ & 0 & 0.66 & Good \\
\hline 20020.FA.1 & Fabiola & & - & 0 & $\mathbf{0}$ & $\mathbf{0}$ & 0.66 & Good \\
\hline 20020.MO.1 & Moneglia & & - & $\mathbf{0}$ & $\mathbf{0}$ & 0 & 0.63 & Good \\
\hline 20020.BA.1 & Baganza & 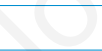 & - & $1(20.0 \%)$ & $4(80.0 \%)$ & 0 & 0,49 & Moderate \\
\hline 20021.TA.1 & Taro & MT & IT4020021 & 0 & $5(83.3 \%)$ & $1(16.7 \%)$ & 0.63 & Good \\
\hline 20021.NA.1 & Naviglio & MT & IT4020021 & 0 & $8(80.0 \%)$ & $2(20.0 \%)$ & 0.52 & Moderate \\
\hline 20021.CE.1 & Ceno & MT & IT4020021 & 0 & $8(88.9 \%)$ & $1(11.1 \%)$ & 0.68 & Good \\
\hline 20022.TA.1 & Taro & $\mathrm{BTa}$ & IT4020022 & 0 & 0 & $19(100.0 \%)$ & 0.30 & Mediocre \\
\hline 20025.PR.1 & Parma Morta & PM & IT4020025 & $\mathbf{0}$ & $\mathbf{0}$ & $\mathbf{0}$ & 0.20 & Bad \\
\hline 20027.EN.1 & Enza & $\mathrm{CV}$ & IT4020027 & 0 & $7(100.0 \%)$ & 0 & 0.72 & Good \\
\hline 30013.EN.1 & Enza & $\mathrm{FE}$ & IT4030013 & 0 & $25(100.0 \%)$ & 0 & 0.55 & Moderate \\
\hline 30013.CE.1 & Cedra & & - & 0 & $2(100.0 \%)$ & 0 & 0.42 & Moderate \\
\hline 30013.CE.2 & Cedra & & - & $\mathbf{0}$ & o & $\mathbf{0}$ & 0.20 & Bad \\
\hline 30014.RV.1 & Rio Vico & $\mathrm{RC}$ & IT4030014 & 0 & $6(100.0 \%)$ & 0 & 0.50 & Moderate \\
\hline 30014.RC.1 & Rio Cerezzola & $\mathrm{RC}$ & IT4030014 & 1 & 0 & 0 & 0.67 & Good \\
\hline 30014.RC.2 & Rio Cerezzola & $\mathrm{RC}$ & IT4030014 & $24(100.0 \%)$ & 0 & 0 & 0.59 & Moderate \\
\hline 30023.EN.1 & Enza & FG & IT4030023 & 0 & $21(91.3 \%)$ & $2(8.7 \%)$ & 0.60 & Moderate \\
\hline 30023.EN.2 & Enza & FG & IT4030023 & 0 & $5(100.0 \%)$ & 0 & 0.53 & Moderate \\
\hline 30023.EN.3 & Enza & FG & IT4030023 & 0 & $5(100.0 \%)$ & 0 & 0.64 & Good \\
\hline 30023.EN.4 & Enza & FG & IT4030023 & $\mathbf{0}$ & $\mathbf{0}$ & 0 & 0.63 & Good \\
\hline
\end{tabular}

ISECI, Ecological Status of Fish Communities. 
as altitude increases. Hence, a progressive improvement of all monitored physical, chemical and morphological features was detected with the decreasing of elevation. The strong overlap between physical and chemical data reinforces the existence of an altitudinal zonation in term of barbel species representativeness among sites. At the site scale, with decreasing altitude the river functionality (e.g., FFI) varied from good to poor/bad, and $\mathrm{BOD}_{5}$ from 0.0 to $20.8 \mathrm{mg} \mathrm{L}^{-1}$.

Our results suggest that the progressive disappearance of well-structured riparian stripes, the increase of the riverbed incision - that actually encourages the progressive isolation of the watercourse from the local context surrounding - and the intense land use change, are the main reasons of the observed zonation. Consequently, the present results obtained through a multidisciplinary approach support the idea that the native and threatened priority barbel species were found preferentially in moderate to well-preserved watercourses, characterized by more expanded riparian areas, in terms of greater IFF values. Similar results were modeled for two Minnesota watersheds, where substantial changes in agricultural management, including an expansion of the riparian areas, would be expected to significantly improve local brook trout [Salvelinus fontinalis (Mitchill, 1814)] populations, by increasing streams shading up to $50 \%$ (Blann et al., 2002). Hence, in lowlands and agricultural settings the destruction of riparian communities leads to a rapid physical and chemical deterioration of watercourses with dramatic effects on fish populations, as highlighted by Lorenzoni et al. (2006) for rivers in Central Italy.

Although the small number of sites under consideration in this work, a quite verified preference of the canine and common barbels for higher IFF values was verified, as a proxy of well-developed and structured riparian contexts and higher altitude values. Marginal vegetated belts are able to efficiently offset the nutrient inputs generated at the basin scale, and to control the main local edaphic factors (Siligardi et al., 2000). Hence, in presence of high FFI values, higher shading values, as well as lower water temperatures and reduced day-night temperature fluctuations are expected. Furthermore, watercourses with high FFI levels should have reduced primary producer rates with rather scarce macrophyte cover values, including algal mats. On the other hand, the alien European barbel was positively and significantly related to high levels of dissolved oxygen, which in turn was associated to higher levels of STT and $\mathrm{BOD}_{5}$. This is not surprising, given that the above-mentioned high dissolved oxygen levels (up to $295 \%$ saturation) were due to the hyper-proliferation of microalgae, and were typical of lowland sites of Po plain where riparian belts/zones have been almost completely lost to land reclamation and by agricultural mechanization (Bolpagni and Piotti, 2015, 2016).

All the above clearly remarks the need for more efficiently designed long-term and wide-spatial scales actions to counteract the alien fish expansion, and furtherly focus on the sustainable management of river habitats and water flows. In this context, the reduction of the hydraulic fragmentation of watercourses is an essential paradigm to improve the survival prospects of a very large number of fish species of conservation interest. In fact, the progressive impairment of the longitudinal river continuity causes significant alterations in river dynamic processes and aquatic vegetation (Bolpagni et al., 2016). However, it is of interest, and possibly of considerable practical importance, taking into account the spatial dynamics of the alien invasive species before operating management actions that
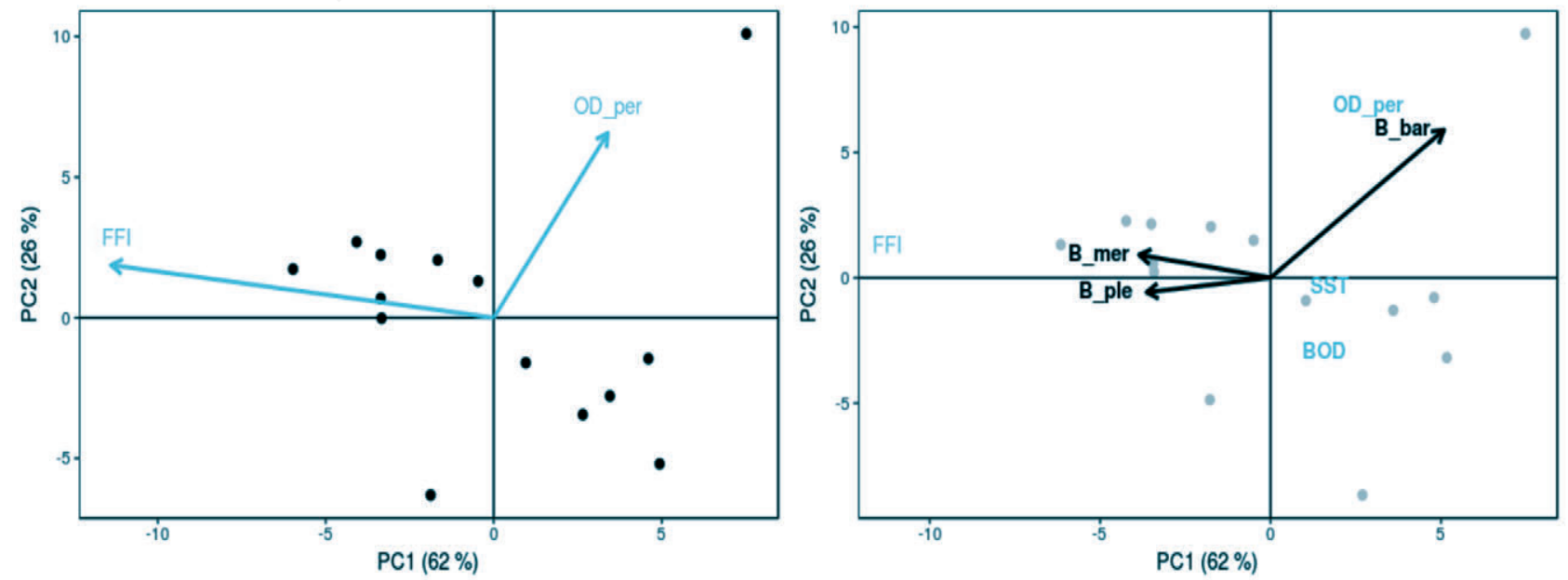

Fig. 2. Results of principal component analysis (left); vectors representing Barbus' population structure. 
could later have an impact to the native fish populations. This critical issue must also be further discussed in the light of the on-going climate change that can affect barbel migration along the altitudinal gradient.

\section{ACKNOWLEDGMENTS}

The present work was performed in the frame of the LIFE project "BARBIE" (LIFE13 NAT/IT/001129) started in 2014. We would thank dr. Erica Racchetti and Marina Vaghi for the support in the laboratory analyses. The contribution of GB is part of her project within the joint doctorate program in Evolutionary Biology and Ecology (XXX cycle) at the Universities of Ferrara and Parma. AL and RB were supported by fellowships cofunded by the University of Parma.

\section{REFERENCES}

Angelini P, Casella L, Grignetti A, Genovesi P, 2016. [Manuali per il monitoraggio di specie ed habitat di interesse comunitario (Direttiva 92/43/CE) in Italia: habitat].[Book in Italian]. ISPRA, Serie Manuali e Linee Guida 142.

APHA, 2012. Standard methods for the examination of water and wastewater. 22nd ed. American Public Health Ass., Washington, DC: $1360 \mathrm{pp}$.

ARPA Emilia Romagna, 2013. [Report sullo stato delle acque superficiali. Triennio 2010-2012].[Book in Italian]. Regione Emilia Romagna: 105 pp.

Blann KL, Nerbonne JF, Vondracek B, 2002. Relationship of riparian buffer type to physical habitat and stream temperature. N. Am. J. Fish. Manage. 22:441-451.

Bolpagni R, Azzella MM, Agostinelli C, Beghi A, Bettoni E, Brusa G, De Molli C, Formenti R, Galimberti F, Cerabolini BEL, 2017. Integrating the Water Framework Directive into the Habitats Directive: analysis of distribution patterns of lacustrine EU habitats in lakes of Lombardy (northern Italy). J. Limnol. 76(Suppl.1):75-83. [Epub 14 Feb 2017].

Bolpagni R, Piotti A, 2015. Hydro-hygrophilous vegetation diversity and distribution patterns in riverine wetlands in an agricultural landscape: a case study from the Oglio River (Po plain, Northern Italy). Phytocoenologia 45:69-84.

Bolpagni R, Piotti A, 2016. The importance of being natural in a human-altered riverscape: Role of wetland type in supporting habitat heterogeneity and vegetation functional diversity. Aquat. Conserv. 26:1168-1183.

Bolpagni R, Racchetti E, Laini A, 2016. Fragmentation and groundwater supply as major drivers of algal and plant diversity and relative cover dynamics along a highly modified lowland river. Sci. Total Environ. 568:875-884.

Borcard D, Gillet F, Legendre P, 2011. Introduction, p. 1-7. In: D. Borcard, F. Gillet and P. Legendre (eds.), Numerical ecology with R. Springer, New York.

Carosi A, Ghetti L, Cauzillo C, Pompei L, Lorenzoni M, 2017. Occurrence and distribution of exotic fishes in the Tiber River basin (Umbria, central Italy). J. Appl. Ichthyol. 33:274-283.
Carrizo SF, Lengyel S, Kapusi F, Szabolcs M, Kasperidus HD, Scholz M, Markovic D, Freyhof J, Cid N, Cardoso AC, Darwall W, 2017. Critical catchments for freshwater biodiversity conservation in Europe: identification, prioritisation and gap analysis. J. Appl. Ecol. 54:1209-1218.

European Commission, 1992. Council Directive 92/43/EEC of 21 May 1992 on the conservation of natural habitats and of wild fauna and flora. OJ L 206, 22/7/1992, p. 7-50.

European Commission, 2000. Directive 2000/60/EC of the European Parliament and of the Council of 23 October 2000 establishing a framework for Community action in the field of water policy. OJ L 327, 22/12/2000, p. 1-73.

Hermoso V, Clavero M, 2011. Threatening processes and conservation management of endemic freshwater fish in the Mediterranean basin: a review. Mar. Freshwater Res. 62:244-254.

Hermoso V, Linke S, Prenda J, Possingham HP, 2011. Addressing longitudinal connectivity in the systematic conservation planning of fresh waters. Freshwater Biol. 56:57-70.

Leprieur A, Beauchard O, Blanchet S, Oberdorff T, Brosse S, 2008. Fish invasions in the world's river systems: When natural processes are blurred by human activities. PLoS Biol. 6:e28.

Lewin W-C, McPhee DP, Arlinghaus R, 2008. Biological impacts of recreational fishing resulting from exploitation, stocking and introduction, p. 75-92. In: Ø. Aas (ed.), Global challenges in recreational fisheries. Blackwell, Oxford.

Li L, Zheng B, Liu L, 2010. Biomonitoring and bioindicators used for river ecosystems: Definitions, Approaches and trends. Procedia Environ. Sci. 2:1510-524.

Lorenzoni M, Mearelli M, Ghetti L, 2006. Native and exotic fish species in the Tiber river watershed (Umbria, Italy) and their relationship to the longitudinal gradient. B. Fr. Peche Piscic. 382:19-44.

Macchio S, Rossi GL, 2014. [Protocollo di campionamento e analisi della fauna ittica dei sistemi lotici guadabili].[Book in Italian]. Manuali e Linee Guida 111/2014, ISPRA: 234 pp.

Meraner A, Venturi A, Ficetola G, Rossi S, Candiotto A, Gandolfi A, 2013. Massive invasion of exotic Barbus barbus and introgressive hybridization with endemic Barbus plebejus in Northern Italy: where, how and why? Mol. Ecol. 22:5295-5312.

Nonnis Marzano F, Pascale M, Piccinini A, 2003. [Atlante dell'ittiofauna della Provincia di Parma].[Book in Italian]. Regione Emilia Romagna, Stilgraf, Viadana: 127 pp.

Oksanen J, Blanchet FG, Kindt R, Legendre P, Minchin PR, O'Hara RB, Simpson GL, Solymos P, Stevens MHH, Wagner H, 2016. vegan: Community Ecology Package. R package version 2.3-5. Available from: https://CRAN.R-project. org/package $=$ vegan

Premstaller G, Cavedon V, Pisaturo GR, Schweizer S, Adami V, Righetti M, 2017. Hydropeaking mitigation project on a multi-purpose hydro-scheme on Valsura River in South Tyrol/Italy. Sci. Total Environ. 574:642-653.

R Core Team, 2015. R: A language and environment for statistical computing. R Foundation for Statistical Computing, Vienna. Available from: https://www.R-project.org/

Siligardi M, Cappelletti C, Chierici E, Ciutti F, Egaddi F, Franceschini A, Maiolini B, Mancini L, Minciardi MM, Monauni C, Rossi GL, Sansoni G, Spaggiari R, Zanetti M, 
2000. [I.F.F. Indice di Funzionalità Fluviale].[Book in Italian]. ANPA, Rome: 223 pp.

Trochet A, Schmeller DS, 2013. Effectiveness of the Natura 2000 network to cover threatened species. Nature Conserv. 4:35-53.

Wickham H, 2009. ggplot2: elegant graphics for data analysis. Springer, New York: 212 pp.
Zardoya R, Doadrio I, 1998. Phylogenetic relationships of Iberian cyprinids: Systematic and biogeographical implications. P. Roy. Soc. Lond. B-Biol. 265:1365-1372.

Zerunian S, Goltara A, Schipani I, Boz B, 2009. [Adeguamento dell'Indice dello Stato Ecologico delle Comunità Ittiche alla Direttiva Quadro sulle Acque 2000/60/CE].[Article in Italian]. Biol. Amb. 23:15-30. 